\title{
The Effects of Customer Satisfaction, Relationship Commitment Dimensions, and Triggers on Customer Retention
}

In a study of telecommunications services, the authors examine the effects of customer satisfaction, affective commitment, and calculative commitment on retention. The study further examines the potential for situational and reactional trigger conditions to moderate the satisfaction-retention relationship. The results support consistent effects of customer satisfaction, calculative commitment, and prior churn on retention. Prior churn also moderates the satisfaction-retention relationship. The results have implications for both customer relationship managers and researchers who use satisfaction surveys to predict behavior.

$\mathbf{M}$ arketing scholars emphasize the influence of customer satisfaction on loyalty (Fornell et al. 1996; Mittal and Kamakura 2001). The relationship management literature emphasizes two different dimensions of relationship commitment that drive loyalty: affective commitment, as created through personal interaction, reciprocity, and trust, and calculative commitment, as created through switching costs (Bendapudi and Berry 1997; Fullerton 2003; Garbarino and Johnson 1999; Morgan and Hunt 1994). Loyalty is often interpreted as actual retention, which is a cornerstone of customer relationship management (CRM). Yet the vast majority of prior research has demonstrated the effects of these constructs only on behavioral intentions. Relatively few studies explain actual behavior (exceptions include Bolton 1998; Bolton and Lemon 1999; Mittal and Kamakura 2001; Verhoef 2003), and to our knowledge, no study examines the effects of all three constructs on retention.

Our goal is to provide insight into the drivers of retention using a combination of survey and longitudinal data from a telecommunications service provider. The research contributes to the CRM literature in three important ways. First, we examine the competing effects of customer satisfaction, affective commitment, and calculative commitment on customer retention. Second, we demonstrate the importance of controlling for heterogeneity (Mittal and Kamakura 2001) or prior loyalty (Guadagni and Little 1983) when predicting retention. Third, we explore the potential for differ-

Anders Gustafsson is Professor of Business Economics (e-mail: Anders. Gustafsson@kau.se), and Inger Roos is Associate Professor of Business Economics (e-mail: inger.roos@ ihroos.fi), Service Research Center, Karlstad University. Michael D. Johnson is D. Maynard Phelps Professor of Business Administration and Professor of Marketing, Stephen M. Ross School of Business, University of Michigan (e-mail: mdjohn@umich.edu). The authors thank Ove Jansson of Telia, Sweden, for providing the data used in the study. ent precipitating events, or "triggers," to moderate the effect of satisfaction on retention.

Effective CRM strategies vary considerably depending on which factors are driving retention. If customer satisfaction is the primary driver of retention, a firm should improve product or service quality or offer better prices. If affective or calculative commitment is more important, a firm should either build more direct relationships with customers or build switching barriers in relation to competitors. Even these strategies may be dependent on the trigger condition that customers face (Smith, Bolton, and Wagner 1999).

\section{The Drivers of Customer Retention}

To understand the complexity of customer loyalty, it is important to understand the evaluations, attitudes, and intentions that affect behavior (Oliver 1999). We focus on three prominent drivers of retention in the marketing literature: overall customer satisfaction, affective commitment, and calculative commitment.

\section{Customer Satisfaction}

Customer satisfaction is defined as a customer's overall evaluation of the performance of an offering to date (Johnson and Fornell 1991). This overall satisfaction has a strong positive effect on customer loyalty intentions across a wide range of product and service categories, including telecommunications services (Fornell 1992; Fornell et al. 1996). As an overall evaluation that is built up over time, satisfaction typically mediates the effects of product quality, service quality, and price or payment equity on loyalty (Bolton and Lemon 1999; Fornell et al. 1996). It also contains a significant affective component, which is created through repeated product or service usage (Oliver 1999). In a service context, overall satisfaction is similar to overall evaluations of service quality. Compared with more episode-based or 
transaction-specific measures of performance, overall evaluations are more likely to influence the customer behaviors that help a firm, such as positive word of mouth and repurchase (Boulding et al. 1993).

Historically, satisfaction has been used to explain loyalty as behavioral intentions (e.g., the likelihood of repurchasing and recommending). However, Verhoef (2003) argues that longitudinal data that combine survey measures with subsequent behavior should be used to establish a causal relationship between perceptions and behavior. For example, Bolton (1998) finds a positive effect of overall customer satisfaction on the duration of the relationship for cellular phone customers, and Bolton and Lemon (1999) show a positive effect of overall satisfaction on customer usage of telecommunications subscription services. In a large-scale study of automotive customers, Mittal and Kamakura (2001) show a strong, albeit nonlinear, effect of customer satisfaction on repurchase behavior, such that the functional form relating satisfaction to repurchase is marginally increasing. They also find large differences in the satisfaction-retention relationship across customer characteristics. On the basis of these studies, we expect customer satisfaction to have a significant influence on customer retention that varies across customers.

\section{Affective and Calculative Commitment}

The relationship marketing literature recognizes another potential driver of customer loyalty: relationship commitment (Bendapudi and Berry 1997; Morgan and Hunt 1994). Drawing on the organizational behavior literature (Meyer and Allen 1997), marketing scholars have variously defined commitment as a desire to maintain a relationship (Moorman, Deshpandé, and Zaltman 1993; Morgan and Hunt 1994), a pledge of continuity between parties (Dwyer, Schurr, and Oh 1987), the sacrifice or potential for sacrifice if a relationship ends (Anderson and Weitz 1992), and the absence of competitive offerings (Gundlach, Achrol, and Mentzer 1995). These various sources create a "stickiness" that keeps customers loyal to a brand or company even when satisfaction may be low.

The various definitions suggest two major dimensions of relationship commitment: affective commitment and calculative, or continuance, commitment (Fullerton 2003; Hansen, Sandvik, and Selnes 2003; Johnson et al. 2001). Calculative commitment is the colder, or more rational, economic-based dependence on product benefits due to a lack of choice or switching costs (Anderson and Weitz 1992; Dwyer, Schurr, and Oh 1987; Heide and John 1992). Affective commitment is a hotter, or more emotional, factor that develops through the degree of reciprocity or personal involvement that a customer has with a company, which results in a higher level of trust and commitment (Garbarino and Johnson 1999; Morgan and Hunt 1994).

In a financial services context, Verhoef (2003) demonstrates direct effects of affective commitment on both relationship maintenance (retention) and relationship development (share of a customer's business). Although both satisfaction and payment equity were positive antecedents of affective commitment, they did not directly affect behavior. Verhoef measured satisfaction using aggregated cus- tomer beliefs about specific dimensions of service performance (e.g., satisfaction with personal attention, willingness to explain procedures, response to claims). In contrast, we measure satisfaction as an overall evaluation of performance (Bolton and Lemon 1999; Fornell et al. 1996). In addition, Verhoef did not include calculative commitment in his study.

An important conceptual difference between customer satisfaction and the commitment dimensions is that satisfaction is "backward looking," whereas the commitment dimensions are more "forward looking." Satisfaction is a function of performance to date, whereas affective and calculative commitment capture the strength of the relationship and the resultant commitment to proceed forward. In our empirical study of telecommunications services, we operationalize customer retention using the degree of churn that occurs in a customer's use of fixed-phone service, cellular phone service, modem-based Internet service, or broadband Internet service. On the basis of the literature, we predict that affective commitment and calculative commitment each has a negative effect on churn (i.e., positive effect on retention).

In our preliminary analyses, we included the effects of price and quality as latent variables on retention. When these constructs were examined on their own, they had a negative effect on churn. However, when we included customer satisfaction in our churn equation, both price and quality became nonsignificant. Because tests of mediation (Baron and Kenny 1986) showed that the effects of price and quality on churn were completely mediated by satisfaction, we excluded these factors from further analysis.

\section{Situational and Reactional Triggers}

In general, a trigger is a factor or an event that changes the basis of a relationship (Roos, Edvardsson, and Gustafsson 2004). In the marketing literature, triggers are frequently cast as alarm clocks that concentrate energy for further actions (Edvardsson and Strandvik 2000; Gardial, Flint, and Woodruff 1996). As we describe in our empirical study, preliminary qualitative interviews support the use of Roos's (1999, 2002) situational and reactional triggers.

Situational triggers alter customers' evaluations of an offering based on changes in their lives or in something affecting their lives. These include demographic changes in the family (e.g., becoming "empty nesters"), changes in job situations, and changes in the economic situations. In a way, the product has expired; it no longer reflects the needs of the customer. In telecommunications, situational triggers may be represented by the need to replace or remove a type of service or subscribe to a different type of service. However, it may take considerable time before the switching path is complete (Keaveney 1995; Roos 1999).

Reactional triggers are those critical incidents of deterioration in perceived performance that are traditionally described in the literature (Gardial, Flint, and Woodruff 1996). When something out of the ordinary occurs, such as a decline in performance before purchase, during purchase, or during consumption, it redirects a customer's attention to evaluate present performance more closely, which may put customers on a switching path (Roos 1999, 2002). For 
example, Bolton (1998) finds that unreported service failures have a significant, negative effect on retention.

The discussion suggests that either a situational or a reactional trigger affects the relevance of pior-performance information when predicting retention. When faced with a situational trigger, customer satisfaction as an overall evaluation of prior performance may become less relevant to the prediction of retention. Similarly, because customers in a reactional trigger condition are actively problem solving, they may focus on present or future performance. Waiting to observe how the company addresses the product or service problem, these customers may put less rather than more stock in prior performance, as measured by overall customer satisfaction. On the basis of these arguments, we predict that that the satisfaction-retention link is weaker for customers in either a situational or a reactional trigger condition.

\section{Empirical Study of Telecommunications Customers}

\section{Qualitative Interviews}

We conducted the research using customers of a large Swedish telecommunications company that provides fixedphone service, mobile phone service, modem-based Internet service, and broadband Internet service. Before we administered the periodic customer survey, we conducted initial qualitative interviews to better understand the triggers that occur in this context. We used a population of customers who had switched from the company either partly (a subset of services) or completely for the initial interviews. Of the 83 customers we contacted for the study, 48 participated in retelling their switching paths. We taped, transcribed, and content analyzed the interviews. Because the main purpose of these interviews was to ensure that the correct triggers were identified for the survey, we summarize the interview results here. Customers classified as having reactional triggers referred to some form of critical incident in which, for example, the customer support was poor or the service was unreliable. Customers classified as having situational triggers identified fundamental changes in their situation, including a lower need to make calls, a greater need to make long-distance calls, or the need to add an Internet supplier.

\section{Periodic Survey}

We used the results of the interviews to develop categories into which customers self-selected on the basis of which statement best described them as a customer. These statements were incorporated into the company's periodic customer survey. In addition to the trigger categories, the survey asked customers to rate the service in question (fixed phone, cellular phone, modem Internet, or broadband Internet) using the multi-item scales that appear in Table 1. Each latent variable had at least three indicators.

The satisfaction questions are the same as those used in the national customer satisfaction barometers (Fornell et al. 1996; Johnson et al. 2001). We adapted the affective and calculative commitment questions from prior studies (John- son et al. 2001; Kumar, Hibbard, and Stern 1994; Meyer and Allen 1997). The affective commitment measures refer to the pleasure in being a customer of the company, the presence of reciprocity in the relationship, trust, and whether the company takes care of its customers. Calculative commitment refers explicitly to the economic consequences of ending the relationship (e.g., based on the company's locations). All statements were rated on a ten-point scale. We conducted a pilot study on 50 respondents to test the questions, during which we encouraged respondents to identify unclear questions. We reworded some of the questions on the basis of feedback from the respondents.

The company's periodic survey is administrated through a professional market research firm. The sample made available for our analysis consisted of 2734 respondents. The ages of the respondents in the sample varied from 18 to 65 years; the mean age was 39.5 years. In addition, $52 \%$ of the respondents were female, and $48 \%$ were male. We asked all respondents to decide whether they belonged to one or more of the trigger conditions or to state explicitly that none of the conditions applied. Two customers did not respond to the trigger questions, and $19 \mathrm{did}$ not have churn data available, which resulted in a final sample size of 2715. Of these, there were $712(26.2 \%)$ fixed phone, 1503 $(55.5 \%)$ mobile phone, 303 (11.2\%) modem-based Internet, and $197(7.3 \%)$ broadband Internet customers. With respect to the trigger conditions, $2249(82.8 \%)$ indicated that no triggers applied, $338(12.4 \%)$ indicated a situational trigger, $197(7.3 \%)$ indicated a reactional trigger, and $69(2.5 \%)$ indicated both a situational and a reactional trigger.

\section{Reliability and Discriminant Validity}

We used principal components analyses to operationalize latent variables from the survey measures. For each set of measures, we extracted the first principal component to create each latent variable for use in subsequent regression analyses. As we show in Table 1, the loadings for the customer satisfaction and the commitment constructs are all relatively large and positive. When these loadings are squared, they indicate the communality of the measure, or the variance that the measure has in common with the latent variable. When the communality measures are standardized, the average communality of a block of indicators is referred to as average variance extracted (AVE) (Fornell and Larcker 1981). The criterion for establishing reliability is that the AVE measures should exceed .5 to ensure that, on average, the measures share at least half of their variation with the latent variable (Fornell and Larcker 1981; Hjorth 1994). As we show in Table 1, the AVE criterion is met for each of the latent variables, which supports the reliability of the measures.

Table 2 presents a correlation matrix for all of the variables used in the churn equations. Here, we focus on the correlations involving the latent constructs. To ensure the discriminant validity of the constructs, Fornell and Larcker (1981) argue that the AVEs of any two constructs should be greater than their squared correlation. When the latent variable correlations in Table 2 are squared (not shown), none exceeds the AVE of the constructs. This supports the discriminant validity of the constructs. 


\begin{tabular}{|c|c|c|c|}
\hline Trigger or Construct & Measure & Loading & $\begin{array}{l}\text { Average } \\
\text { Variance } \\
\text { Extracted }\end{array}$ \\
\hline Situational trigger & $\begin{array}{l}\text { There has been a recent change in your working } \\
\text { conditions, family situation, or living conditions that has } \\
\text { caused you to consider switching to another operator. }\end{array}$ & N.A. & N.A. \\
\hline Reactional trigger & $\begin{array}{l}\text { There has been a recent change in your relationship with } \\
\text { the company that has caused you to consider switching } \\
\text { to another operator, such as poor service, receiving a } \\
\text { faulty invoice, or something similar. }\end{array}$ & N.A. & N.A. \\
\hline \multirow[t]{3}{*}{ Customer satisfaction } & $\begin{array}{l}\text { 1: Overall satisfaction ( } 1 \text { = "very dissatisfied," } 10 \text { = "very } \\
\text { satisfied") }\end{array}$ & .901 & .766 \\
\hline & $\begin{array}{l}\text { 2: Expectancy disconfirmation ( } 1 \text { = "falls short of } \\
\text { expectations," } 10=\text { "exceeds expectations") }\end{array}$ & .895 & \\
\hline & $\begin{array}{l}\text { 3: Performance versus the customer's ideal service } \\
\text { provider in the category ( } 1=\text { "not very close to ideal } \\
\text { provider," } 10=\text { "very close to ideal provider") }\end{array}$ & .827 & \\
\hline \multirow[t]{4}{*}{ Affective commitmenta } & 1: I take pleasure in being a customer of the company. & .798 & .692 \\
\hline & $\begin{array}{l}\text { 2: The company is the operator that takes the best care } \\
\text { of their customers. }\end{array}$ & .837 & \\
\hline & $\begin{array}{l}\text { 3: There is a presence of reciprocity in my relationship } \\
\text { with the company. }\end{array}$ & .825 & \\
\hline & 4: I have feelings of trust toward the company. & .865 & \\
\hline \multirow[t]{3}{*}{ Calculative commitmenta } & $\begin{array}{l}\text { 1: It pays off economically to be a customer of the } \\
\text { company. }\end{array}$ & .862 & .630 \\
\hline & $\begin{array}{l}\text { 2: I would suffer economically if the relationship were } \\
\text { broken. }\end{array}$ & .833 & \\
\hline & $\begin{array}{l}\text { 3: The company has location advantages versus other } \\
\text { companies. }\end{array}$ & .674 & \\
\hline
\end{tabular}

aAgree-disagree scale (1 = "strongly disagree," 10 = "strongly agree").

Notes: N.A. $=$ not applicable.

\section{Churn Measures}

We include customer satisfaction $\left(\mathrm{CS}_{\mathrm{t}}\right)$, affective commitment $\left(\mathrm{AC}_{\mathrm{t}}\right)$, calculative commitment $\left(\mathrm{CC}_{\mathrm{t}}\right)$, a situational trigger condition $\left(\mathrm{ST}_{\mathrm{t}}\right)$, and a reactional trigger condition $\left(\mathrm{RT}_{\mathrm{t}}\right)$, all in time $\mathrm{t}$, to predict churn in time $\mathrm{t}+1\left(\mathrm{Churn}_{\mathrm{t}+1}\right)$ using ordinary least squares regression. We collected the survey variables from customers who were using fixedphone, cellular phone, modem-based Internet, or broadband Internet service at time t. We matched the periodic survey data with customers' account data for the service through their telephone number and an identification number. The account data included a monthly churn measure for each customer beginning with the first periodic survey in April 2003 and continuing through August 2004 (17 months). Because the survey is periodic, a complete 17 months of behavioral data are available only for a small sample of cus- tomers. To retain our sample size, we explored relatively short windows for churn. We explored measures of the total amount of churn, which we defined as the total number of months over a given period that the customer was not retained, over a 3-, 6-, and 9-month period. Because there was more variation using the 9-month cumulative churn measure, we relied on this measure to test our predictions.

Thus, we surveyed our test sample from April to November of 2003, with nine months of account data available through August 2004. Because customers were using the service in question (or were retained) in the month they responded to the survey, Churn $_{t+1}$ captures the total months of churn in the nine months following the survey. The average churn is 3.52 months (standard deviation [s.d.] = 3.738). Because we surveyed respondents over different time periods, we used the month in which we surveyed the 
TABLE 2

Correlation Matrix of Latent Variables, Triggers, and Churn

\begin{tabular}{|c|c|c|c|c|c|c|c|}
\hline & $C S_{t}$ & $A C_{t}$ & $C c_{t}$ & $\mathrm{ST}_{\mathrm{t}}$ & $\mathrm{RT}_{\mathrm{t}}$ & Churn $_{t-1}$ & Churn $_{t+1}$ \\
\hline$A C_{t}$ & $\begin{array}{c}.748 \\
(.000)\end{array}$ & & & & & & \\
\hline $\mathrm{CC}_{\mathrm{t}}$ & $\begin{array}{c}.519 \\
(.000)\end{array}$ & $\begin{array}{c}.545 \\
(.000)\end{array}$ & & & & & \\
\hline $\mathrm{ST}_{\mathrm{t}}$ & $\begin{array}{c}-.243 \\
(.000)\end{array}$ & $\begin{array}{c}-.225 \\
(.000)\end{array}$ & $\begin{array}{l}-.173 \\
(.000)\end{array}$ & & & & \\
\hline $\mathrm{RT}_{\mathrm{t}}$ & $\begin{array}{c}-.256 \\
(.000)\end{array}$ & $\begin{array}{c}-.248 \\
(.000)\end{array}$ & $\begin{array}{c}-.143 \\
(.000)\end{array}$ & $\begin{array}{c}-.191 \\
(.000)\end{array}$ & & & \\
\hline Churn $_{t-1}$ & $\begin{array}{c}-.090 \\
(.000)\end{array}$ & $\begin{array}{c}-.088 \\
(.000)\end{array}$ & $\begin{array}{c}-.117 \\
(.000)\end{array}$ & $\begin{array}{l}.035 \\
(.065)\end{array}$ & $\begin{array}{c}-.033 \\
(.086)\end{array}$ & & \\
\hline Churn $_{t+1}$ & $\begin{array}{c}-.130 \\
(.000)\end{array}$ & $\begin{array}{c}-.119 \\
(.000)\end{array}$ & $\begin{array}{c}-.150 \\
(.000)\end{array}$ & $\begin{array}{c}.054 \\
(.005)\end{array}$ & $\begin{array}{c}-.010 \\
(.606)\end{array}$ & $\begin{array}{l}.757 \\
(.000)\end{array}$ & \\
\hline Fixed $_{t}$ & $\begin{array}{l}.050 \\
(.009)\end{array}$ & $\begin{array}{l}.051 \\
(.008)\end{array}$ & $\begin{array}{c}.054 \\
(.005)\end{array}$ & $\begin{array}{l}.016 \\
(.401)\end{array}$ & $\begin{array}{c}-.025 \\
(.198)\end{array}$ & $\begin{array}{c}-.265 \\
(.000)\end{array}$ & $\begin{array}{c}-.254 \\
(.000)\end{array}$ \\
\hline
\end{tabular}

Notes: $\mathrm{N}=2715$; significance levels are in parentheses (two-tailed test). $\mathrm{CS}=$ customer satisfaction, $\mathrm{AC}=$ affective commitment, $\mathrm{CC}=\mathrm{calcu}$ lative commitment, ST = situational trigger, and $\mathrm{RT}$ = reactional trigger.

customer as a fixed factor in our preliminary analysis of churn. This time factor did not approach significance, and thus we omitted it from further analyses.

Preliminary estimation of the churn models also included a four-level fixed factor to capture differences in the type of service studied. We included all possible interaction effects involving this fixed factor and found only a main effect difference in average months of churn among the fixed-phone customers (1.93) and the other services (4.09). For parsimony, we collapsed the four-level factor into a dummy variable, Fixed $_{t}$, to indicate fixed-phone service; we included this as a control variable.

It is important to control for heterogeneity across customers when predicting retention (Mittal and Kamakura 2001). Churn data were available for the four months before the month during which a customer was using a service and participated in the periodic satisfaction survey. We define Churn $_{t-1}$ as the total number of months in which customers were not using the service before the survey; the average is 1.46 months of prior churn (s.d. = 1.749). Use of this prior churn as a state-dependent variable to predict future churn helps control for heterogeneity. It explains variation in churn due to the inherent predisposition of some customers to switch and others to remain loyal. We also explore the potential for a weaker satisfaction-retention relationship among those customers who are predisposed to churn.

\section{Churn Models and Results}

The analyses all assume that the relationships between the latent variables and our churn measure are linear. Recall that Mittal and Kamakura (2001) find a nonlinear (marginally increasing) relationship between vehicle satisfaction and repurchase. Although our churn measure is relatively short term (ranging from zero months of churn to nine complete months of churn), we estimated nonlinear relationships between each of our key latent variables (customer satisfaction, affective commitment, and calculative commitment) and churn. In each case, the linear component was significant, whereas neither the quadratic nor cubic terms approached significance. This suggests that the relationships are essentially linear.

Given the collinearity among the latent variables and their interaction terms, we use a series of regression equations to predict churn. We first estimate the effects of prior performance, in the form of overall customer satisfaction, on churn. We include the effects of prior churn to capture heterogeneity and type of service as a control variable:

(1) Churn $_{\mathrm{t}+1}=\beta_{0}+\beta_{1} \mathrm{CS}_{\mathrm{t}}+\beta_{2}$ Churn $_{\mathrm{t}-1}+\beta_{3}$ Fixed $_{\mathrm{t}}$,

where Churn $\mathrm{t}_{\mathrm{t}+1}$ is the total months of churn (0-9) postsurvey, $\mathrm{CS}_{\mathrm{t}}$ is customer satisfaction measured in the survey at time $\mathrm{t}$, Churn $_{\mathrm{t}-1}$ is total months of churn (0-4) presurvey, and Fixed ${ }_{t}$ is a dummy variable to capture whether the service involved fixed-phone service. Table 3 reports the standardized parameters for the churn equations and their significance; it also reports the variance explained for each equation.

Equation 1 shows significant effects of customer satisfaction, prior churn, and fixed-phone service. Churn decreases with satisfaction, increases with prior churn, and decreases for fixed-phone customers. That satisfaction predicts behavior is consistent with previous studies (Bolton 1998; Bolton and Lemon 1999; Mittal and Kamakura 2001). That prior churn influences future churn is consistent with Mittal and Kamakura's (2001) findings that there is significant heterogeneity in the satisfaction-retention relationship. The standardized parameters suggest that prior churn has a relatively large effect on churn. As we describe subsequently, the relatively short time horizon involved helps explain this result.

In our second churn model, we explore whether addition of the commitment constructs adds significant predictors of churn:

(2)

$$
\begin{gathered}
\text { Churn }_{\mathrm{t}+1}=\beta_{0}+\beta_{1} \mathrm{CS}_{\mathrm{t}}+\beta_{2} \mathrm{AC}_{\mathrm{t}}+\beta_{3} \mathrm{CC}_{\mathrm{t}}+\beta_{4} \text { Churn }_{\mathrm{t}-1} \\
+\beta_{5} \text { Fixed }_{\mathrm{t}} .
\end{gathered}
$$

When we include affective and calculative commitment in the model, all previously included variables remain signifi- 


\section{Churn Model}

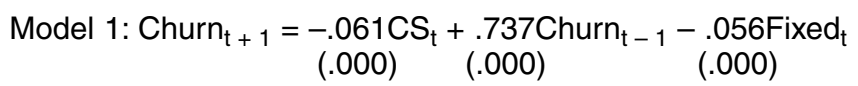

Model 2: Churn $_{\mathrm{t}+1}=-.040 \mathrm{CS}_{\mathrm{t}}+.000 \mathrm{AC}_{\mathrm{t}}-.040 \mathrm{CC}_{\mathrm{t}}+.734$ Churn $_{\mathrm{t}-1}-.055$ Fixed $_{\mathrm{t}}$

$\begin{array}{llll}(.036) & (1.000) \quad(.008) \quad(.000) & (.000)\end{array}$

Model 3: Churn $_{\mathrm{t}+1}=-.065 \mathrm{CS}_{\mathrm{t}}-.039 \mathrm{CC}_{\mathrm{t}}+.735$ Churn $_{\mathrm{t}-1}+.038 \mathrm{CS}_{\mathrm{t}} \times$ Churn $_{\mathrm{t}-1}-.055$ Fixed $_{\mathrm{t}}$

Model 4: Churn $_{t+1}=-.068 \mathrm{CS}_{\mathrm{t}}-.038 \mathrm{CC}_{\mathrm{t}}+.734$ Churn $_{\mathrm{t}-1}+.014 \mathrm{ST}_{\mathrm{t}}+.001 \mathrm{RT}_{\mathrm{t}}+.039 \mathrm{CS}_{\mathrm{t}}$

$$
\begin{array}{lllll}
(.001) & (.010) & (.000) & (.336) & (.963)
\end{array}
$$

$$
\begin{aligned}
& \times \text { Churn }_{\mathrm{t}-1}-.001 \mathrm{CS}_{\mathrm{t}} \times \mathrm{ST}_{\mathrm{t}}+.015 \mathrm{CS}_{\mathrm{t}} \times \mathrm{RT}_{\mathrm{t}}-.056 \mathrm{Fixed}_{\mathrm{t}} \\
& \text { (.931) }
\end{aligned}
$$

Notes: We report the standardized coefficients, with significance levels in parentheses (two-tailed test).

cant. Whereas calculative commitment becomes a significant predictor of churn, affective commitment does not.

Note from Table 2 that customer satisfaction and affective commitment are highly correlated latent variables. If we remove customer satisfaction from Equation 2, the main effect of affective commitment becomes significant. Although our top-down, or theoretical, analysis of reliability and discriminant validity supports separate satisfaction and affective commitment constructs, their correlation and our results suggest that they are capturing similar information. To understand this issue better, we conducted an exploratory principal components analysis of the survey measures (with Varimax rotation). This bottom-up, or datadriven, analysis reveals two principal components with eigenvalues greater than one; these account for $62.9 \%$ of the variation in the survey measures. The three measures of customer satisfaction and the four measures of affective commitment load highest on the first component (average loading $=.759$ ), whereas the four measures of calculative commitment load highest on the second component (average loading $=.727$ ). This analysis demonstrates that both satisfaction and affective commitment capture customers' overall evaluation of the offering. In contrast, calculative commitment captures more of the competitive nature of the offering with respect to switching costs or the availability of viable alternatives. In our subsequent churn equations, we keep customer satisfaction and remove affective commitment because satisfaction is the significant predictor.

We then estimate two churn equations to explore the potential for interactions. Customers who are predisposed to churn or switch may be less sensitive to priorperformance information. This suggests that the effect of customer satisfaction on churn is lower for customers who are prone to churn. To explore this prediction, we include the interaction between satisfaction and prior churn as follows:

$$
\begin{gathered}
\text { Churn }_{t+1}=\beta_{0}+\beta_{1} \mathrm{CS}_{\mathrm{t}}+\beta_{2} \mathrm{CC}_{\mathrm{t}}+\beta_{3} \text { Churn }_{\mathrm{t}-1} \\
+\beta_{4} \mathrm{CS}_{\mathrm{t}} \times \text { Churn }_{\mathrm{t}-1}+\beta_{5} \text { Fixed }_{\mathrm{t}} .
\end{gathered}
$$

Equation 3 reveals a significant interaction between customer satisfaction and prior churn. The significant, positive coefficient for this interaction $(.038, p=.022)$ demonstrates that the negative main effect of satisfaction on churn (-.065, $p<.000)$ is indeed lower for customers with a history of prior churn. We ran other models (not reported) that represent variations on Equation 3. For example, when we substitute affective commitment for customer satisfaction, we obtain the same pattern of results. When we include other possible two- and three-way interactions, they are not significant.

Finally, we explore the potential for the situational and reactional trigger conditions to influence churn. We add to Equation 3 the main effects of the triggers on churn and their potential to moderate the satisfaction-retention relationship:

$$
\text { (4) } \begin{aligned}
\text { Churn }_{\mathrm{t}+1} & =\beta_{0}+\beta_{1} \mathrm{CS}_{\mathrm{t}}+\beta_{2} \mathrm{CC}_{\mathrm{t}}+\beta_{3} \mathrm{ST}_{\mathrm{t}}+\beta_{4} \mathrm{RT}_{\mathrm{t}} \\
& +\beta_{5} \mathrm{Churn}_{\mathrm{t}-1}+\beta_{6} \mathrm{CS}_{\mathrm{t}} \times \text { Churn }_{\mathrm{t}-1}+\beta_{7} \mathrm{CS}_{\mathrm{t}} \times \mathrm{ST}_{\mathrm{t}} \\
& +\beta_{8} \mathrm{CS}_{\mathrm{t}} \times \mathrm{RT}_{\mathrm{t}}+\beta_{9} \text { Fixed }_{\mathrm{t}} .
\end{aligned}
$$

Although this model replicates the results from Equation 3, none of the trigger main effects or interactions are significant. Again, the addition of all possible two- and three-way interactions to this equation reveals no other significant effects. Thus, Equation 3 captures the consistent predictors of churn in our data.

\section{Discussion and Implications}

Customer relationship managers benefit from a thorough understanding of the various factors that drive retention. The customer satisfaction and relationship marketing literature suggests three predictors of retention: overall customer satisfaction, affective commitment, and calculative commitment. Customer satisfaction is an overall evaluation of performance to date, affective commitment captures the trust and reciprocity in a relationship, and calculative commitment captures the existence of switching costs or lack of viable alternatives. Prior research has used only a subset of these constructs to explain behavior.

Our study contributes to the marketing literature in several ways. First, we combine customer satisfaction, affective commitment, and calculative commitment to predict 
retention. Second, we control for heterogeneity in the satisfaction-retention relationship by incorporating both the main and moderating effects of prior churn. Third, we explore for the potential moderating effects of situational and reactional triggers on the satisfaction-retention relationship. Finally, by combining a telecommunications company's periodic customer survey with longitudinal account data, we provide support for causal relationships between the survey measures and subsequent behavior.

Several important findings emerge. In line with prior studies, customer satisfaction has a consistent negative effect on churn (a positive effect on retention). In contrast, affective commitment does not predict churn when it is included with customer satisfaction. Although Verhoef (2003) finds the opposite result (i.e., affective commitment rather than satisfaction predicts retention), it is important to recognize the differences in measurement variables between his study and ours. Recall that his measure of satisfaction was an aggregate of attribute performance ratings, whereas ours is a latent variable based on three overall evaluations of performance (overall satisfaction, performance versus expectations, and performance versus an ideal provider in the category). Our findings suggest that when satisfaction is measured as an overall evaluation of performance, it indeed predicts churn.

Affective commitment is also measured differently in the two studies. Verhoef (2003) operationalizes affective commitment using agreement ratings for the statements: "I am a loyal customer of XYZ," and "Because I have a strong attachment to (sense of belonging with) XYZ, I want to remain a customer of XYZ." In contrast, our measures of affective commitment are agreement ratings for statements about the pleasure or positive affect in being a customer of the company: whether the company takes care of its customers, the presence of reciprocity in the relationship, and feelings of trust toward the company (for exact wording, see Table 1). Whereas our measures focus more on the theoretical basis of affective commitment, Verhoef's measures are akin to behavioral intentions. However, an exploratory principal components analysis reveals that our satisfaction and affective commitment measures tap the same overall evaluations. Further research should explore ways to delineate satisfaction from affective commitment without relying on behavioral intentions.

Another important finding is that calculative commitment, a construct not included in previous studies of retention, has a consistent negative effect on churn. This calculative commitment is important because it captures the competitiveness of the value proposition. Whereas customer satisfaction and affective commitment focus on perceptions of an offering per se, calculative commitment reflects the viability of competitive offerings. This finding is analogous to research that supports the effects of "should" expectations on customer perceptions. Boulding and colleagues (1993) find that customer expectations about what a company should deliver decreases perceptions of performance. What customers know about competitive offerings presumably affects these "should" expectations.

Two other findings involve the effects of prior churn on future churn. Rather than rely solely on psychometric con- structs to explain churn, we included prior churn as a statedependent variable to explain subsequent churn. This is a relatively simple way for relationship managers to control for the heterogeneity across customers with respect to predisposition to churn. Although prior churn has the largest effect on churn in our equations, we expect that this is due to the relatively short time period involved. With only a nine-month window of behavior to explain, it is difficult for the survey constructs to compete with prior churn. We also find a significant interaction between prior churn and customer satisfaction. Customer satisfaction has more (less) influence on churn for those customers who are inherently prone to stay (switch).

We also explored the potential for situational and reactional trigger conditions to influence churn. The trigger literature suggests that triggers may either lower retention directly or lower the effects of customer satisfaction on retention. However, the triggers did not affect either retention or the satisfaction-retention relationship. Although our study did not detect any trigger effects, the existence of triggerlike effects in other studies (Bolton 1998; Seiders et al. 2005) suggest that they remain an important topic for further research. We expect that our triggers simply take more than nine months to create a switching path.

\section{CRM Implications}

Our study suggests that customer relationship managers should include both overall evaluations of performance (e.g., customer satisfaction) and the viability of competitive offerings (e.g., calculative commitment) in periodic surveys used to predict retention. Whereas customer satisfaction is commonly included in such surveys, calculative commitment is not. Calculative commitment helps capture the competitive element that is often missing when predicting retention. The actions that CRM managers take depend on which of these factors has the greatest influence on churn. If customer satisfaction is the key driver, retention programs and efforts should focus on improving satisfaction whether or not competitors are doing the same things. In contrast, if calculative commitment is the key driver, the emphasis shifts to improving the aspects of the value proposition that are more unique to the offering. In other words, calculative commitment forces managers to think beyond improving satisfaction to consider specifically how to improve their competitive advantage.

Of further importance to relationship managers is the need to control for heterogeneity in the satisfactionretention relationship. We offer a relatively simple solution: Include prior churn in the analysis. This enables relationship managers to understand the effects of customer satisfaction and relationship commitment on retention beyond inherent differences in customers' propensities to churn. Not only are some customers predisposed to stay or to churn, but they are also more or less sensitive to changes in customer satisfaction. By identifying which customers are prone to stay with a provider and likely to respond to satisfaction improvement efforts, managers stand to improve their return on marketing investment.

Although our trigger predictions were not supported, this is still relevant for relationship management. In some 
highly competitive and dynamic market environments, such as cellular phones, what a company does to keep customers over the next few months may be critical to its survival. Our results show that neither a situational nor a reactional trigger has a significant main effect or moderating effect when added to our churn models. This suggests that relationship managers need not worry about trigger conditions in the short run. In the long run, however, the situation may differ considerably. Our data follow the customers' behavior for only nine months, and triggers often take time to work. Although customers may be aware of a situational or reactional trigger, the effect on actual behavior may be delayed. If such triggers are shown to have an effect over a longer period, identifying them early gives a relationship manager some lead time to intervene and prevent switching.

Finally, our study has implications for researchers who use periodic surveys to explain behavior. Following traditional rules for evaluating the reliability and discriminant validity of latent variables, our analyses support the use of customer satisfaction, affective commitment, and calculative commitment as separate predictors of churn. A subse- quent exploratory principal components analysis suggests that satisfaction and affective commitment tap the same customer perceptions, whereas calculative commitment captures something different. Across studies, however, there are considerable differences as to how affective commitment is measured. The challenge for researchers is to find a better way to discriminate satisfaction and affective commitment as backward- versus forward-looking evaluations of an offering.

A limitation of our study is that we explore only nine months of retention. We expect an improvement in the ability of the survey variables and trigger conditions to predict retention as this time frame increases. Another possible limitation is that customers self-selected into the various trigger conditions using the company's own survey. However, we identified the trigger categories using qualitative interviews from a separate sample of the company's customers. More in-depth interviews with the customers who actually responded to the survey would help ensure the more accurate prediction of the type of switching path each customer may be on (Roos 2002).

\section{REFERENCES}

Anderson, Erin and Barton Weitz (1992), "The Use of Pledges to Build and Sustain Commitment in Distribution Channels," Journal of Marketing Research, 29 (February), 18-34.

Baron, Reuben M. and David A. Kenny (1986), "The ModeratorMediator Variable Distinction in Social Psychological Research," Journal of Personality and Social Psychology, 51 (6), 1173-82.

Bendapudi, Neeli and Leonard L. Berry (1997), "Customers' Motivations for Maintaining Relationships with Service Providers," Journal of Retailing, 73 (1), 15-37.

Bolton, Ruth N. (1998), "A Dynamic Model of the Duration of the Customer's Relationship with a Continuous Service Provider: The Role of Satisfaction," Marketing Science, 17 (Winter), 45-65.

— and Katherine N. Lemon (1999), “A Dynamic Model of Customers' Usage of Services: Usage as an Antecedent and Consequence of Satisfaction," Journal of Marketing Research, 36 (May), 171-86.

Boulding, William, Ajay Kalra, Richard Staelin, and Valarie A. Zeithaml (1993), "A Dynamic Process Model of Service Quality: From Expectations to Behavioral Intentions," Journal of Marketing Research, 30 (February), 7-27.

Dwyer, F. Robert, Paul H. Schurr, and Sejo Oh (1987), "Developing Buyer-Seller Relationships," Journal of Marketing, 51 (April), 11-27.

Edvardsson, Bo and Tore Strandvik (2000), "Is a Critical Incident Critical for a Customer Relationship?" Managing Service Quality, 10 (2), 82-91.

Fornell, Claes (1992), "A National Customer Satisfaction Barometer: The Swedish Experience," Journal of Marketing, 56 (January), 6-21.

- Michael D. Johnson, Eugene W. Anderson, Jaesung Cha, and Barbara Everitt Bryant (1996), "The American Customer Satisfaction Index: Nature, Purpose, and Findings," Journal of Marketing, 60 (October), 7-18.

— and David F. Larcker (1981), "Evaluating Structural Equation Models with Unobservable Variables and Measurement Error," Journal of Marketing Research, 18 (February), 39-50.

Fullerton, Gordon (2003), "When Does Commitment Lead to Loyalty?" Journal of Service Research, 5 (May), 333-44.
Garbarino, Ellen and Mark S. Johnson (1999), “The Differential Roles of Satisfaction, Trust, and Commitment in Customer Relationships," Journal of Marketing, 63 (April), 70-87.

Gardial, Sarah Fisher, Daniel J. Flint, and Robert B. Woodruff (1996), "Trigger Events: Exploring the Relationships Between Critical Events and Consumers' Evaluations, Standards, Emotions, Values and Behavior," Journal of Consumer Satisfaction, Dissatisfaction and Complaining Behavior, 9, 35-51.

Guadagni, Peter M. and John D.C. Little (1983), "A Logit Model of Brand Choice Calibrated on Scanner Data," Marketing Science, 2 (Summer), 203-238.

Gundlach, Gregory T., Ravi S. Achrol, and John T. Mentzer (1995), "The Structure of Commitment in Exchange," Journal of Marketing, 59 (January), 78-92.

Hansen, Håvard, Kåre Sandvik, and Fred Selnes (2003), "Direct and Indirect Effects of Commitment to a Service Employee on the Intention to Stay," Journal of Service Research, 5 (May), 356-68.

Heide, Jan and George John (1992), "Do Norms Matter in Marketing Relationships?" Journal of Marketing, 56 (April), 32-44.

Hjorth, Urban J.S. (1994), Computer Intensive Statistical Methods: Validation Model Selection and Bootstrap. London: Chapman \& Hall.

Johnson, Michael D. and Claes Fornell (1991), "A Framework for Comparing Customer Satisfaction Across Individuals and Product Categories," Journal of Economic Psychology, 12 (2), 267-86.

- Anders Gustafsson, Tor Wallin Andreassen, Line Lervik, and Jaesung Cha (2001), "The Evolution and Future of National Customer Satisfaction Index Models," Journal of Economic Psychology, 22 (April), 217-45.

Keaveney, Susan M. (1995), "Customer Switching Behavior in Service Industries: An Exploratory Study," Journal of Marketing, 59 (April), 71-82.

Kumar, N., J.D. Hibbard, and L.W. Stern (1994), "The Nature and Consequences of Marketing Channel Intermediary Commitment," Working Paper No. 94-115. Cambridge, MA: Marketing Science Institute. 
Meyer, John and Natalie Allen (1997), Commitment in the Workplace: Theory, Research and Application. Thousand Oaks, CA: Sage Publications.

Mittal, Vikas and Wagner Kamakura (2001), "Satisfaction, Repurchase Intent, and Repurchase Behavior: Investigating the Moderating Effects of Customer Characteristics," Journal of Marketing Research, 38 (February), 131-42.

Moorman, Christine, Rohit Deshpandé, and Gerald Zaltman (1993), "Factors Affecting Trust in Market Relationships," Journal of Marketing, 57 (January), 81-101.

Morgan, Robert M. and Shelby D. Hunt (1994), "The Commitment-Trust Theory of Relationship Marketing," Journal of Marketing, 58 (July), 20-38.

Oliver, Richard L. (1999), "Whence Consumer Loyalty?” Journal of Marketing, 63 (Special Issue), 33-44.

Roos, Inger (1999), "Switching Processes in Customer Relationships," Journal of Service Research, 2 (August), 376-93.

- (2002), "Methods of Investigating Critical Incidents: A Comparative Review," Journal of Service Research, 4 (February), 193-204.
Bo Edvardsson, and Anders Gustafsson (2004), "Customer Switching Patterns in Competitive and Non-Competitive Service Industries," Journal of Service Research, 6 (February), 256-71.

Seiders, Kathleen, Glenn B. Voss, Dhruv Grewal, and Andrea L. Godfrey (2005), "Do Satisfied Customers Buy More? Examining Moderating Influences in a Retailing Context," Journal of Marketing, 69 (October), 26-43.

Smith, Amy K., Ruth N. Bolton, and Janet Wagner (1999), "A Model of Customer Satisfaction with Service Encounters Involving Failure and Recovery," Journal of Marketing Research, 36 (August), 356-72

Verhoef, Peter C. (2003), "Understanding the Effect of Customer Relationship Management Efforts on Customer Retention and Customer Share Development," Journal of Marketing, 67 (October), 30-45. 
Copyright of Journal of Marketing is the property of American Marketing Association. The copyright in an individual article may be maintained by the author in certain cases. Content may not be copied or emailed to multiple sites or posted to a listserv without the copyright holder's express written permission. However, users may print, download, or email articles for individual use. 